\title{
An adequate minimum code: a basis for freedom, justice and efficiency in the labour market
}

\author{
Peter Brosnan and David Rea*
}

This paper explores the case for expanding and improving the minimum code of employment protections. A framework is developed for understanding the various "floors" which provide protection for individuals within society. It is then argued that recent changes to these protections, in particular the Employment Contracts Act and the decline in social welfare entitlements, have left many people vulnerable to exploitation and poverty. Strengthening the minimum code provides a solution to this problem. A better level of basic protections are also a spur to productivity. The paper argues that an adequate minimum code encourages a more efficient use of labour.

\section{Introduction}

The debate over the Employment Contracts Act has drawn attention to the fact that New Zealand has a basic floor of employment rights. This floor of employment rights, or minimum code, is a range of statutory provisions which provide minimum terms and conditions of employment for almost all workers. Although it is only recently that statutory employment protections have become known as the minimum code, they have, for nearly a century, been an important component of labour market regulation. Recently, the significance of the basic employment protections provided by the floor of rights has increased. The National Government's radical structural changes to the industrial relations system has simultaneously drawn attention to the existence of the minimum code and created a need for it to be expanded and improved.

Without an adequate floor of employment rights, the Employment Contracts Act 1991 is seriously deficient. The new regime makes disadvantaged groups, - especially Maori, Pacific Island people, women, youth and some older workers, - more vulnerable to exploitation. The new legislation will greatly expand the number of workers employed in the segments of the labour market characterized by a self-reinforcing cycle of low pay, disadvantage and discrimination.

Furthermore, the Employment Contracts Act has the potential to promote economic inefficiency. With the growth in low paid, casualized employment, firms will have no incentives to invest in either worker training, or more efficient production techniques.

These outcomes necessitate an expanded and improved minimum code, if deprivation and inefficiency are to be minimized. In this article we argue that the Government should take the following steps. First, the code should be widened by the inclusion of additional legal minima. As an example, statute should define a minimum required period of notice before employer termination of the employment contract. Secondly, many of the existing protections should be improved. For example, the level of the minimum wage should be increased, and it should be widened to cover workers under 20 years of age.

* Industrial Relations Centre, Victoria University of Wellington. The authors would like to thank Stuart McCaw, Moira Wilson and the editors for their helpful ideas and comments. 
Thirdly, there should be a regular assessment and modification of the minimum code through a consultative process. These steps will bring New Zealand into line with many of the developments in European labour law (Deakin, 1990). Instead of being simply a safety net, an improved minimum code should provide a floor of rights which would then provide an adequate base for individual and collective bargaining.

\section{Floors of social minima}

The living standards enjoyed by individual members of a society depend primarily on their access to cash income. Their level of consumption is determined by what they can afford to buy and their capacity for having the value of these purchases augmented by production in the home; for example, making one's own clothes and preparing foods from basic ingredients, but the range of domestic production is limited both by social convention and therefore the availability of the basic inputs. Moreover, the time taken up by domestic production reduces the time available for paid work and therefore the income to pay for the basic inputs to domestic production. Thus everyone in a modern capitalist society must have direct, or indirect, access to monetary income to finance consumption.

The extent to which each person is able to finance consumption varies enormously. A small proportion of the population have access to interest income, or the profits of companies in which they hold shares. Another small group, some farmers, may have a degree of self-sufficiency. Approximately a third of the population have wage or salary incomes from full time jobs, but the rest, a majority, have to rely on support from other family members, part time work, the social welfare system, or some combination of these. Even this depiction is a little too simple, for now the social welfare system is being used to supplement the incomes of full time workers whose wages are inadequate for supporting other family members.

A person's status and freedom is determined fundamentally by the level and source of the finance for consumption. Those with secure, well paid, full time jobs are free from dependence on others' income, and are ascribed positive values within society. Moreover, their income gives them power over other persons, such as their non-earning spouse or children, whose living standards are determined by the level of consumption which the wage earner is prepared to allow. The converse of this is that individuals who are reliant on others for the finance of their consumption are ipso facto unfree, and are ascribed fewer positive values. Thus wage earners are credited with more kudos than unemployed persons or family members, usually women, who augment the value of the monetary income through domestic labour.

The freedom and status of individuals without access to full time employment can be enhanced by the social welfare system. For example, women who have access to a welfare income, such as the Domestic Purposes Benefit, can escape dependence on a marital relationship. Similarly unemployed workers; the availability of an unemployment benefit allows them to maintain their consumption and frees them from dependence on private charity. It also gives them some independence from employers, since the benefit level acts as a wage floor below which they would not have to work.

But while the social welfare system reduces the degree of dependence on other family members, and on private charity, it creates a different level of dependence; dependence on the State, for the State is, on the one hand, benign and, on the other hand, coercive. In developing the social welfare system, governments have been motivated to protect citizens from absolute deprivation, but at the same time, they have also been concerned to protect traditional family structures and to maintain the relative advantage of employers in the labour market. Thus New Zealand welfare benefits are usually means tested against family income and invariably set well below the prevailing level of wages. One consequence is that young school leavers and women (or men) who cannot obtain full 
time employment are denied access to social welfare in their own right and are forced into a dependent relationship on their parents or husband (or wife). In the case of young people, this prolongs the period of their "childhood". In the case of married women, their economic contribution is limited to undervalued domestic labour and, although the need for this increases with reduced cash income, they suffer a drop in status.

Moreover, the low level of benefits makes existence precarious; thus, in times of high unemployment, unemployed workers are often forced to accept inferior jobs. And benefit levels tend to move countercyclically. When the economy is in recession, the number of unemployed increases and tax revenues decline. The government response is often to cut benefits, thus reinforcing the precarious situation of all workers.

When workers become welfare beneficiaries, they experience a drop in income and a drop in status. This is encouraged by governments, and employers, but a distinction is made among the different categories of beneficiary. Retired workers or war veterans are generally treated as deserving of their pensions. People with disabilities and orphans are considered to be entitled to "public charity". Unemployed workers and single parents are given less sympathy, and are often depicted as being responsible for their own situation. One of the sad ironies of the business cycle is that the greater the number of unemployed, and thus the less the likelihood of finding a job, the more intense are the attacks on the status of unemployed people.

Given these relationships between a person's economic position in society, their status, and their standard of living, levels of welfare benefits and wages are the crucial determinants of individual and family liberty. Consequently governments have endeavoured over the last century to influence these through a variety of measures. The extent and complexity of welfare benefits has grown while direct and indirect regulation of the labour market has proceeded in tandem. Until this year, State labour market regulation has been based upon the award system supplemented by individual bargaining, both, in turn, regulated by a combination of statute and the common law, and both underpinned by a floor of statutory rights. The combination of welfare and labour market regulation has created a series of floors which provide different levels of protection for individuals, depending on their position, whether within or without the labour market. The only groups not protected by these floors are persons who are incapable of claiming their due rights, and illegal residents who have no rights.

The main floors of support are illustrated by figure 1. As the diagram shows, persons without employment and no other form of support suffer absolute deprivation. They can therefore fall to the level (a) in the diagram. Examples of such people are young persons unsupported by their families, and unable, or ineligible, to negotiate the social welfare bureaucracy. The most visible group in this category are street kids. Without access to support, their only option is begging or crime. For those who are able to claim welfare benefits, the level of public support provides a different limit to their living standards. They can fall no lower than the level (c). There are many, however, who have no entitlement in their own right and must therefore rely on private support through families, churches and charitable agencies. They can therefore fall as low as level (b).

These different floors provide some protection for employed people against exploitation. The diagram shows, however, that different workers have different floors of protection. The majority of employed workers are protected by the minimum code. Thus they can fall no lower than the level (e). Some categories of worker do not get the benefit of the minimum code. For example there is no minimum wage for teenagers. Thus the effective floor of wages for them is the social welfare system (d). Very young workers, illegal workers (e.g. overstayers), and those who cannot negotiate alternative benefits, can fall to the levels provided by private support or below - (j) and (k) in the diagram. 
Figure 1: Floors of employment rights and other protections against deprivation
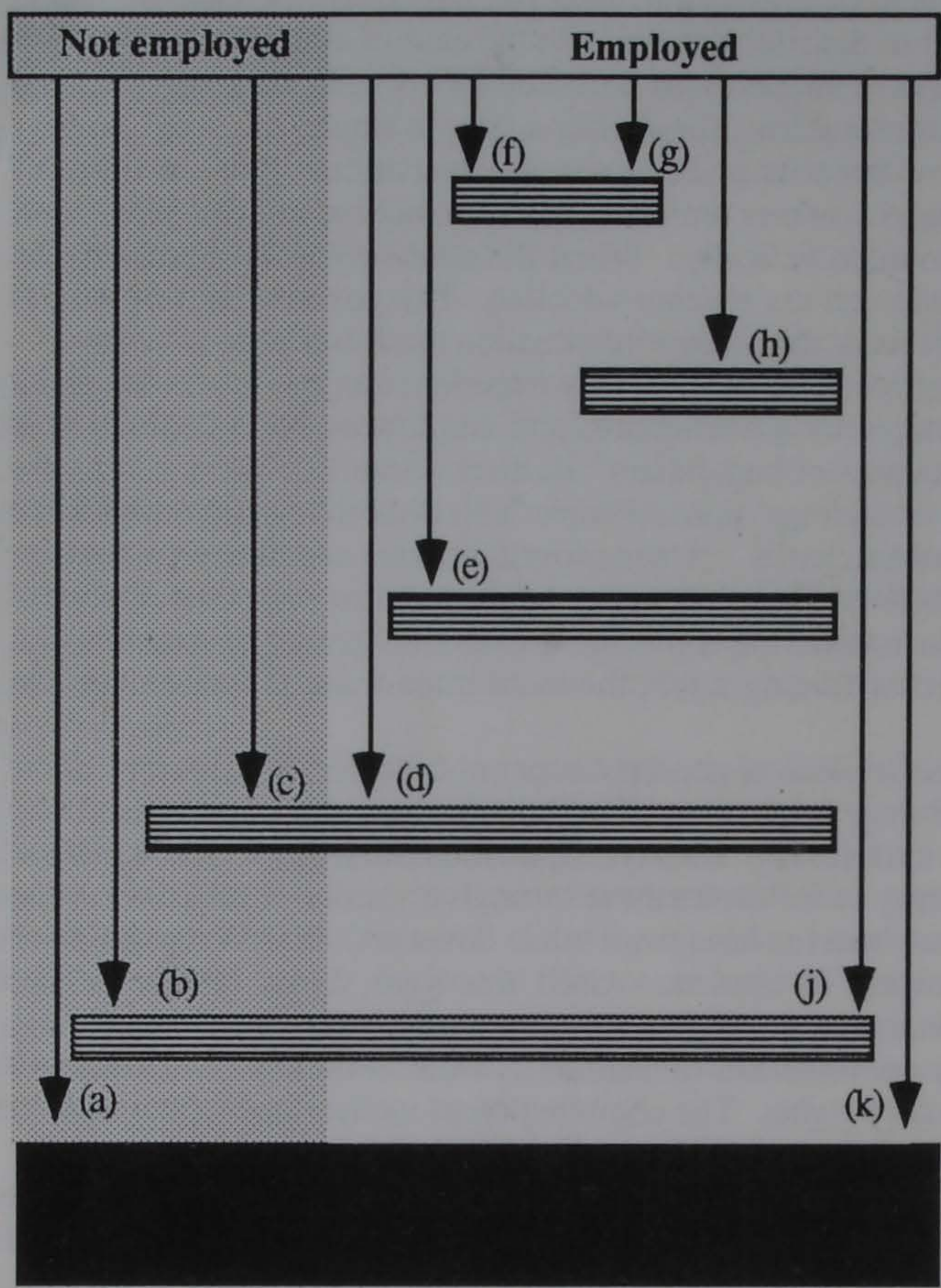

Above award agreements Individual contracts, second tier bargaining

Awards and agreements Employment minima

\section{Minimum code}

Statutory minimum floor of employment rights

\section{Public support}

Social welfare, public health, accident compensation, etc.

\section{Private support}

Family, social networks, private charity, etc.

Absolute deprivation

The conciliation and arbitration system provided a more substantial floor of minimum terms and conditions in particular industries and occupations for workers employed in those trades. Thus workers covered by awards or agreements had a floor which prevented them falling below the levels specified in those documents (the level $(\mathrm{h})$ in the diagram). The economic, social and political power possessed by certain groups primarily white educated males - allowed them to achieve levels of support higher than that provided in awards. Managers and some other white collar workers did not have awards but could negotiate superior conditions, well above the levels in awards - shown as (f) in the diagram. Some groups which had awards could negotiate better conditions than provided by awards, either on an individual basis, or codified as collective agreements (before 1987 referred to as second tier bargaining). These levels are depicted as (g) in the diagram.

The industrial conciliation and arbitration system and the social welfare system, were the main mechanisms by which the State provided protection to individuals in the labour market. However, as the earlier discussion and the depiction in figure 1 illustrates, the system was not entirely comprehensive and some groups of workers were left without coverage. Because of this, the statutory minima which formed the minimum code provided an important additional level of protection. The development of these 3 different forms of labour market regulation began largely with the legislative programme of the Liberal Governments in the 1890s. 


\section{Development of the minimum code}

Until 1991, the principles of the Industrial Conciliation and Arbitration Act 1894 have been the celebrated mainstay of the industrial relations framework. The system combined stable trade unionism with bargaining centred around minimum terms and conditions of employment contained in awards. Disputes surrounding the negotiation and interpretation of these documents were resolved through conciliation and arbitration procedures. The latter was provided through the Arbitration Court or its successors, and this developed into an important policy instrument for the regulation of labour market outcomes. As an industrial relations framework, the industrial conciliation and arbitration system promoted productivity, at the same time as attempting to protect workers from exploitation. Awards and trade unions provided workers (who were covered by the system) with a degree of protection against exploitation. Productivity was promoted because the industrial relations system delivered bargaining outcomes at a low cost, with a minimum of industrial disruption and enforced similar wages and conditions on all employers. Those which could not pay these wages were, therefore, forced to become more efficient or go out of business.

The 1890s also saw the beginning of state sponsored welfare. The hardships of the economic depression of the late 1880s led to the development of an ethos of state responsibility for the welfare of individuals. This period of Liberal government saw the development of the education and health system and the implementation of pensions for the aged. However, it was not until the First Labour Government, and in particular the Social Security Act 1938, that a comprehensive system of social welfare was constructed. This system, which provided support for the unemployed, and subsidized consumption, strengthened the labour market position of those individuals least able to protect themselves in the labour market.

The foundations of the minimum code were laid, in the nineteenth century with legislation such as the Employment of Females Act 1873. The 1890 Sweating Commission provided the impetus for the further development of the minimum code. The Commission's investigations which uncovered a range of exploitative employment practices, which had arisen during the long depression of the $1870 \mathrm{~s}$ and $1880 \mathrm{~s}$, were influential in the Liberal Government's legislative programme of the 1890 s.

Protection against unscrupulous employers paying workers in goods or kind was provided by the Truck Act 1891 . Also, the Factories Acts of 1891 and 1894 controlled hours of work and the manner in which wages could be paid, as well as creating a system of health and safety codes enforced by factory inspectors. Given the concern with "sweated labour", a major focus of the legislative programme was to regulate the employment of disadvantaged groups. Of interest in this regard was the Employment of Boys or Girls without Payment Prevention Act 1899. This act fixed a universal minimum wage for young workers under 20 years of age. The Act stipulated that every young person under 18 years of age was to receive not less than 5 shillings ( 50 cents) a week, with an annual increment of not less than 3 shillings (30 cents) weekly until reaching the age of 20 (Woods, 1963). ${ }^{1}$

For the majority of workers, the system worked well. This was largely because they were covered by awards and the protections of the industrial conciliation and arbitration system. However, for some workers there was no relevant award, and no effective trade union. This meant that they had to rely on the protection of statutory minima. After the onset of World War II, the Government found it necessary to direct labour to specific occupations. Concern that some of these jobs were not covered by awards led the Labour

1 In 1990 dollars, this translates to $\$ 28$ per week for 18 year olds, plus an extra $\$ 17$ dollars per week for each additional year. This is clearly low compared to modern wage and benefit levels. Nevertheless, it provided a minimum for 18 and 19 year olds in excess of their entitlements today. 
Government to improve the statutory minimum floor of employment conditions. Labour's new protections included a guarantee of 2 weeks annual holidays for all workers (Annual Holidays Act 1944), and a minimum wage set by regulation. The latter was given statutory form with the Minimum Wage Act 1945. This created a minimum wage for adult workers with different rates for males and females (Brosnan and Wilkinson, 1989).

Since that time, the minimum code has been periodically updated and improved. A third week of annual holidays was added in 1974. Various protections against discrimination have been implemented. The Equal Pay Act 1972, the Human Rights Commission Act 1977 and the Employment Equity Act 1990 (now repealed) outlawed discrimination in the employment of certain groups. Also of interest, was the recognition of the statutory right to parental leave with the Parental Leave and Employment Protection Act 1987.

Thus, in the last century, the different forms of state sponsored employment protection have evolved and expanded together. However, with the Employment Contracts Act and the retrenchment in welfare entitlements, the range of labour market protections have changed fundamentally. This fact seems to have been recognized by the Minister of Labour. At the time of promoting the new legislation, he promised to strengthen the minimum code of employment protections (Media statement, 23 April 1991). Unfortunately, it was soon obvious that the Minister's intention was simply to retain, rather than greatly expand, many of the existing statutory minima. Apart from an extension and a slight increase in leave entitlements (amendment to the Holidays Act 1981), and a rearrangement of personal grievance provisions (the Employment Contracts Act 1991), the code remained largely unchanged. Thus, disadvantaged segments of the labour-force are left with the meagre range of statutory employment protections listed below:

(i) The Minimum Wage Act 1983 provides a statutory minimum floor for the wages of workers over the age of 20 . The actual rate is prescribed by a Minimum Wage Order, the most recent being $\$ 245$ for a 40 hour week. As can be seen from table 1 , the real value of the minimum wage has declined considerably since its inception in 1945.

(ii) The Wages Protection Act 1983 provides for the manner in which wages must be both paid, and deducted, by an employer.

(iii) The Holidays Act 1981 provides for minimum entitlements of holidays and leave. The Act specifies 11 paid statutory holidays for each worker. Allowing for weekends, these amount to an average of 8 days per year. The Act also stipulates that workers, after each year of employment, are allowed 3 weeks annual holidays on pay (or the cash equivalent if a worker quits before taking holidays). There is also provision for 5 days paid special leave for sickness, domestic or bereavement reasons after 6 months of employment.

(iv) The Equal Pay Act 1972 provides for a limited measure of equal pay. Differentiation in pay rates on the grounds of sex is not allowed. Additionally, discrimination on the grounds of race, colour, sex, marital status, religion or country of origin in the hiring, firing, training or promotion of workers is made illegal by the Human Rights Commission Act 1977 and the Race Relations Act 1971.

(v) The Parental Leave and Employment Protection Act 1987 provides for unpaid parental leave. Eligibility for this leave is guaranteed if a worker has been employed for at least 10 hours a week for over one year. Parental leave ensures that employees are entitled to have their jobs kept open for 52 weeks on the basis of maternity, paternity, extended or special leave. The entitlements are for both males and females, before, during, or after pregnancy or adoption. The Act also prohibits the use of pregnancy as grounds for dismissal. 
Table 1: Minimum wage and average earnings

\begin{tabular}{lcccc}
\hline Year & $\begin{array}{c}\text { Minimum weekly } \\
\text { wage }\end{array}$ & $\begin{array}{c}\text { Mean ordinary time } \\
\text { weekly earnings }\end{array}$ & $\begin{array}{c}\text { Real value of } \\
\text { minimum weekly } \\
\text { wage (March } \\
1991 \text { prices) }\end{array}$ & $\begin{array}{c}\text { Minimum wage as } \\
\text { a proportion of } \\
\text { mean earnings }\end{array}$ \\
\hline & $(1)$ & $(2)$ & & $(1) /(2)$ \\
$1948^{\mathrm{a}}$ & $11.50^{\mathrm{c}}$ & $\$$ & $\$$ & \\
$1951^{\mathrm{a}}$ & $13.17^{\mathrm{c}}$ & 14.75 & 268.00 & 0.78 \\
$1954^{\mathrm{a}}$ & $17.50^{\mathrm{c}}$ & 19.52 & 263.74 & 0.67 \\
$1957^{\mathrm{a}}$ & $18.75^{\mathrm{c}}$ & 24.24 & 283.50 & 0.72 \\
$1960^{\mathrm{a}}$ & $19.75^{\mathrm{c}}$ & 25.27 & 275.73 & 0.74 \\
$1963^{\mathrm{a}}$ & $20.33^{\mathrm{c}}$ & 27.70 & 263.24 & 0.71 \\
$1966^{\mathrm{a}}$ & $21.67^{\mathrm{c}}$ & 30.99 & 257.20 & 0.66 \\
$1969^{\mathrm{a}}$ & $23.50^{\mathrm{c}}$ & 35.36 & 250.32 & 0.61 \\
$1972^{\mathrm{a}}$ & $27.00^{\mathrm{c}}$ & 41.90 & 237.09 & 0.56 \\
$1975^{\mathrm{a}}$ & $54.88^{\mathrm{c}}$ & 60.97 & 219.59 & 0.44 \\
$1978^{\mathrm{a}}$ & $64.41^{\mathrm{d}}$ & 91.61 & 343.33 & 0.60 \\
$1981^{\mathrm{b}}$ & $80.16^{\mathrm{d}}$ & 132.18 & 261.92 & 0.49 \\
$1984^{\mathrm{b}}$ & $84.17^{\mathrm{d}}$ & 215.89 & 207.98 & 0.37 \\
$1987^{\mathrm{b}}$ & $210.00^{\mathrm{d}}$ & 279.33 & 161.73 & 0.30 \\
$1990^{\mathrm{b}}$ & $245.00^{\mathrm{d}}$ & 396.92 & 266.27 & 0.53 \\
$1991^{\mathrm{b}}$ & $245.00^{\mathrm{d}}$ & 505.99 & 256.10 & 0.48 \\
\hline & & 530.64 & 245.00 & 0.46 \\
\hline
\end{tabular}

Source: Brosnan and Wilkinson (1989).

Notes: a April

b February

c Males

d Males and females

(vi) The Volunteers Employment Protection Act 1973 provides that unpaid leave can be taken for military service.

(vii) The Factories and Commercial Premises Act 1981, along with 30 other pieces of legislation, and over 50 regulations, deal specifically with, or have some relevance to, occupational health and safety issues. The focus of the legislation is the provision of safety standards, with administrative responsibility spanning a number of different government agencies.

(viii) The Employment Contracts Act 1991 requires every contract to contain a personal grievance procedure, and provides a standard procedure where one has not been stipulated. The procedure is able to be invoked when a worker feels they have been unfairly dismissed, disadvantaged, discriminated against by the employer, or sexually harassed at work. In contrast to the Industrial Relations Act 1973, where access to personal grievance provisions was through awards, and the Labour Relations Act 1987, where access was via union membership, the new regime ensures that all workers are covered by a procedure. This effectively widens the coverage of personal grievance procedures, most significantly for managerial and other workers not previously covered by awards. The Employment Contracts Act also provides a disputes procedure to solve disputes arising out of the interpretation, application or operation of an employment contract. Furthermore, the Act requires that wages and time records be kept by an employer, and these, together with a 
written copy of the employment contract, must be available to the worker on request.

Although the new legislation expands the floor of rights, the net effect has been to make things worse. By replacing awards with collective contracts, and significantly increasing the difficulty of collective action by workers, the new legislation has effectively removed a whole level of basic protections at the level of industries and occupations (see figure 1). This, combined with reduced social welfare provisions, has removed the protections which many workers once enjoyed.

\section{The impact of the Employment Contracts Act on the labour market}

The need for an expansion and improvement of the minimum code is clearly evident given the impact of the Employment Contracts Act on labour market interaction. This is because the labour market regulation provided by the new regime will significantly increase the intensity of segmentation and further accentuate patterns of disadvantage. These effects become apparent, given an understanding of the existing structure of the labour market, as well as the manner in which labour markets work.

Unfortunately, much of the political justification for the new legislation has been based on a simplistic model of labour market adjustment. This has led to the assertion that the new regime will increase productivity. In particular, the Minister of Labour argued that productivity would be enhanced by removing the restrictive work practices of the award system (New Zealand Herald, 21 January 1991, p.6). However, apart from anecdotes of dubious significance, there seems to be little evidence to support such a proposition (Harbridge, 1990). Traditionally, a significant proportion of employers provided employment on terms and conditions over and above those stipulated by the award. Only a minority of employers, often the very worst, were actually constrained by the award system. This is backed up by a recent survey which indicated that many small employers felt contented with the previous system of industrial relations. The researchers argue that "...most of these [surveyed] employers function basically unencumbered by unions or the labour relations system. This majority are untroubled by the national award system" (McAndrew and Hursthouse, 1991, p.9).

At a broader level, much of the economic argument in support of the new legislation relates to labour market flexibility (Treasury; 1987, 1990). It is asserted that the new legislation will create wage rates which, because they are responsive to imbalances in the supply and demand of labour, provide more efficient co-ordination of the labour market. Such responsiveness is argued to lead to increased employment and enhanced prospects for the disadvantaged. It is assumed that competition, mediated by a flexible wage, will produce a labour market where workers of comparable productivity are rewarded equally. Within this paradigm, unemployment results from the absence of competition or a properly functioning price mechanism. Proponents of this view argue that creating a flexible wage mechanism which gives the unemployed the ability to underbid currently employed workers will provide an efficiency gain. It is claimed both that unemployment will disappear, and firms will be able to replace low productivity employed workers with high productivity unemployed workers.

Unfortunately these arguments are based upon a false set of assumptions about the nature of labour markets and the sources of productivity gains. The misplaced emphasis on the productivity of individual workers obscures the fact that productivity is largely a creation of the internal organization of the firm. The relatively small differences in the supply characteristics of workers are unimportant. More important determinants of the productive efficiency of firms are the choice of production techniques, the efficiency of managerial structures, and the sophistication and utilization of capital. 
The great weakness which undermines the view of the supporters of the new legislation is their assumption that real world labour markets could, or should, function in the same way as financial markets, or the simple models of economic textbooks. But employers do not regard workers as homogeneous, nor do they want workers to compete constantly for each others jobs. The reality is that labour is highly differentiated and competition between workers for jobs, and between firms for labour, is limited by a the differing needs of firms and the characteristics of individual workers. These barriers to competition, which are intrinsic to labour markets, create segments of non-competing groups.

Labour market segmentation results from the nature of the employment relationship. In contrast to the interaction which occurs in a spot auction market for goods, the labour market does not involve an exchange of clearly defined property rights. Instead, wages are exchanged for a promise of work. Firms are interested in purchasing labour, but instead purchase labour power (Bowles and Gintis, 1975). This labour market exchange creates a long term, socially constructed, strategic interaction between workers and employers called the employment relationship. This relationship changes the nature of competition in the labour market, and creates segmentation and non-competing groups. Firm-specific human capital (Oi, 1962), differential exit costs, internal labour markets (Doeringer and Piore, 1971), the existence of social differentiation of workers through educational socialization (Bowles and Gintis, 1975), occupational licensing (Marsden, 1986), trade unions (Rubery, 1978), the impact of domestic work (Humphries and Rubery 1984), discrimination (Roemer, 1979), and social networks (Mainwaring, 1984) are processes which may lead to segmentation. These characteristics of labour market interaction lead to separate markets or segments for different categories of workers. The result is that the labour market provides differential rewards to workers of comparable productivity.

Segmentation occurs both on the demand and supply side. On the demand side, the labour market is differentiated into segments according to the structure of jobs and occupations. As an example, the differing degrees of firm specific human capital in jobs may give rise to different types of employment. At the same time, the labour market is also differentiated into segments according to the social group supplying labour. For example, education produces a differentiated labour supply. The reinforcement of social roles, combined with barriers to participation, thus leads the education system to segment labour supply.

The result of segmentation in both the supply and demand for labour is that that socially advantaged and powerful groups are able to secure access to the better jobs in the "primary" segments. In contrast, disadvantaged groups and those who cannot secure employment in good jobs, are relegated to "secondary" segments. ${ }^{2}$

Segmentation causes the burden of labour market adjustment to be shared unequally. Within primary segments, the structure of employment ensures that unemployed workers are imperfect substitutes for employed workers. The result is that wages in the primary segments are relatively sticky, and there may be incentives for firms to maintain the level of real wages, despite a significant excess supply of labour. Advantaged workers in "good" jobs are therefore insulated from the effects of competition.

In contrast, the structure of employment in the secondary segments ensures that the unemployed are close substitutes for workers in "bad" jobs. The wages and conditions of workers in these jobs are therefore significantly responsive to changes in the supply or demand for labour. Disadvantaged workers in the secondary sector suffer the worst effects of competition because their terms and conditions of employment are significantly responsive to labour market imbalances. Instead of equalizing the return to skill or

2 The terms primary and secondary segments are used heuristically. Rather than a dual labour market distinction, the terms are intended to point to the existence of a broad range of rewards for occupations of comparable productivity (Ryan,1981). 
productivity, competition ensures that those least able to protect themselves suffer hardship and exploitation.

Table 2: The occupational distribution of the labour force 1986

\begin{tabular}{|c|c|c|c|}
\hline Occupational groups & $\begin{array}{c}\text { Non } \\
\text { Polynesian }\end{array}$ & Maori & $\begin{array}{c}\text { Pacific Island } \\
\text { Polynesian }\end{array}$ \\
\hline \multicolumn{4}{|l|}{ Males $(\mathrm{N}=841338)$} \\
\hline Proportion of workforce & 89.8 & 7.5 & 2.7 \\
\hline Professionals & 14.2 & 3.9 & 2.9 \\
\hline Administrators and managers & 11.5 & 2.4 & 1.2 \\
\hline Clerical workers & 5.2 & 2.9 & 4.6 \\
\hline Sales workers & 7.4 & 2.1 & 1.5 \\
\hline Supervisors & 4.6 & 3.9 & 4.0 \\
\hline Skilled manual workers & 31.8 & 24.0 & 28.9 \\
\hline Unskilled manual workers & 24.5 & 58.9 & 52.6 \\
\hline Not specified & 0.8 & 2.0 & 4.3 \\
\hline Total: & 100.0 & 100.0 & 100.0 \\
\hline \multicolumn{4}{|l|}{ Females $(\mathrm{N}=436866)$} \\
\hline Proportion of workforce & 89.3 & 7.6 & 3.1 \\
\hline Professionals & 19.5 & 9.6 & 5.7 \\
\hline Administrators and managers & 5.8 & 2.1 & 1.2 \\
\hline Clerical workers & 32.3 & 17.3 & 16.8 \\
\hline Sales workers & 10.1 & 4.5 & 1.9 \\
\hline Supervisors & 2.9 & 3.1 & 1.9 \\
\hline Skilled manual workers & 11.6 & 14.1 & 21.5 \\
\hline Unskilled manual workers & 17.2 & 47.3 & 47.5 \\
\hline Not specified & 0.6 & 2.0 & 3.7 \\
\hline Total: & 100.0 & 100.0 & 100.0 \\
\hline
\end{tabular}

Source: Computed from 1986 Census, Series C, Vols. 4, 9 and 10.

The processes responsible for the structuring of the labour market during the last century of New Zealand history have produced a high concentration of disadvantaged groups in certain industries and occupations (table 2). Traditional labour market policies, particularly the conciliation and arbitration system, moderated the worst excesses of exploitation found in unregulated labour markets elsewhere, and largely prevented the development of a dual structure. However in doing this, they nevertheless allowed a particular pattern of segmentation to continue and develop. As an example, the industrial relations system often perpetuated wage relativities which maintained some occupations as low paid. At the same time, unemployment, employer discrimination, state policies which discouraged labour force participation, differentiated educational systems, and low returns to educational qualifications for some groups created a particular labour market 
structure. The result, as table 3 implies, is that women, youth, Maori and Pacific Island Polynesian workers are currently concentrated disproportionately in low paid marginal segments (Brosnan and Wilson, 1989).

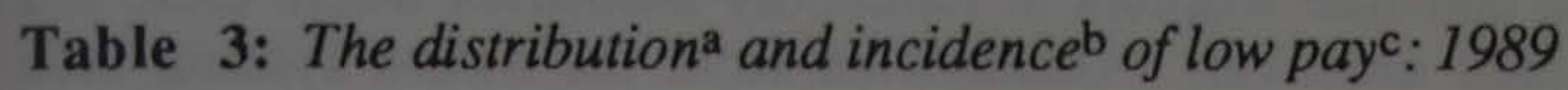

\begin{tabular}{|c|c|c|c|c|}
\hline \multirow{3}{*}{ Ethnic origin } & \multicolumn{2}{|c|}{ Males } & \multicolumn{2}{|c|}{ Females } \\
\hline & Distribution & Incidence & Distribution & Incidence \\
\hline & $\%$ & $\%$ & $\%$ & $\%$ \\
\hline Pakeha & 81.8 & 20.9 & 80.8 & 37.3 \\
\hline Maori & 7.8 & 26.9 & 8.4 & 52.6 \\
\hline Pacific Island & 5.9 & 45.7 & 6.4 & 66.5 \\
\hline Other & 4.2 & 38.6 & 3.6 & 51.8 \\
\hline Not specified & 0.2 & 35.8 & 0.7 & 81.2 \\
\hline All ethnic origins & 100.0 & 22.4 & 100.0 & 39.9 \\
\hline
\end{tabular}

Source: Special analysis of 1988/1989 Household Expenditure and Income Survey data prepared for Low Pay Unit, Department of Labour.

Notes: a Distribution is the number of low paid workers in the category as a percentage of all low paid workers.

b Incidence is the number of low paid workers in the category as a percentage of all workers in the category.

c Less than 68 percent of mean adult earnings.

History has thus bequeathed New Zealand with a labour market structure characterized by inequality and a significant degree of persistent disadvantage. It is this structure which now becomes the base for the competitive individualized contracting of the Employment Contracts Act 1991. Supporters argue that the new legislation will both erode this pattern of disadvantage and promote employment. It is more likely however, that the new system of industrial relations will accentuate the existing levels of disadvantage, and hinder economic growth.

It is possible to make a number of predictions as to the effects of the new law given an understanding of labour market segmentation. The Employment Contracts Act 1991, by increasing the intensity of competition in the labour market, will lead to increased segmentation, poor productivity, less training, possibly negative employment growth, and the imposition of significant external costs on society.

\section{Labour market effects - increased segmentation}

The new legislation will accentuate the varying ability of different groups of workers to manipulate the supply and demand of labour. Because of this, advantaged groups will 
maintain, and in some cases increase, their levels of remuneration from the labour market. In contrast, disadvantaged and socially powerless groups of workers will suffer declines in their terms and conditions of employment.

Some types of occupations in the labour market are shielded from the effects of competition. For example, consider workers in monopoly industries where there is a history of strong and militant unionism. Unshackled from the award system, their conditions of employment may remain constant or, in some cases, even increase. Thus heightened labour market competition will not necessarily erode the terms and conditions of employment for many advantaged groups of workers. Traditionally this has been demonstrated by senior managers and professionals. Although many of these groups have not been unionized, they have been able to use their power to maintain, or even improve their pay and conditions, despite economic downturns.

This can be contrasted with the probable fate of disadvantaged workers who are concentrated in occupations which suffer the burden of labour market adjustment. Consider the experience of young people in an intensely competitive labour market. Young people are either concentrated at "ports of entry" within internal labour markets, or within the secondary sector. A significant amount of labour market adjustment occurs in these areas because the unemployed are close substitutes. At times of an excess supply of labour, young entrants to the labour market experience significant changes in wages, stability of tenure, and probability of unemployment. Without significant external protections, these young workers become vulnerable to exploitation.

Of most concern, the Employment Contracts Act 1991 is a licence to create secondary sector employment. Thus we shall see a labour market characterized by worsening inequality. There will be an increasing concentration of Maori, women, youth and Pacific Island workers in marginalized, low paid and casualized occupations. The new legislation will intensify the culture of inefficiency, minimal training, discrimination and low pay in these disadvantaged segments.

\section{The impact on the firm - poor productivity}

In contrast to much of the current rhetoric of its supporters, the new legislation is likely to retard growth in productivity and employment. This can be argued even with the traditional economic model whole-heartedly endorsed by Treasury and the Business Roundtable. According to that model, firms choose a profit maximizing combination of capital and labour, based on their relative prices determined in competitive markets. However, because of the barriers to competition which give rise to labour market segmentation, there is no essential reason why wage rates under the new regime should approximate those that would exist under perfect competition. A "second best argument" (Lancaster and Lipsey, 1956) raises the possibility that increased labour market competition may accentuate the divergence of wages from the standard of perfect competition. This could also lead firms to choose inefficient and unproductive combinations of labour and capital.

If a more realistic model of the firm is used, the proposition that low pay will result in poor productivity is even more convincing. Enabling firms to compete using low wage strategies provides no incentives for the efficient utilization of labour. Worse than that, low wages actually provide an incentive to maintain out-dated production technologies. This will further intensify economic stagnation because it deflects attention from the real issues in productivity - improvements in capital and the deployment of skilled workers.

The current cost of labour influences not only the firm's demand for labour given the current capital stock, but also decisions made by the firm in relation to both capital investment, and research and development. The historically irreversible nature of technological change ensures that self-reinforcing cycles perpetuate low wages and low 
productivity. A decline in wage rates provides entrepreneurs with no incentive to upgrade the productive process, and this reinforces low wages. The positive alternative is to increase wages and therefore "shock" firms into up-dating technology. This will then increase productivity and spur further increases in wages.

\section{The impact on workers - creating an unskilled workforce.}

The new legislation will retard the development of a skilled workforce. This is because low pay, the growth of atypical or non-standard employment, and an enlarged secondary sector, all discourage training. Firms have no incentive to train when labour is cheap or workers are seen as disposable. The same applies to employers using atypical employment forms such as temporary employment or feigned self employment. Workers who are forced into feigned self employment (such as owner drivers) are unlikely to receive training. Their de facto "employers" have no incentives to train them. Furthermore, the workers themselves, as the de jure employers, rarely have the resources to fund their own training. This seems to have been demonstrated by a recent investigation into the forestry sector where contracting has lead to lower levels of training (Hamid, 1988). Declining levels of skill acquisition thus further reinforce low productivity and low growth. The Act will therefore perpetuate the existence of the low skilled, low productivity segments of the labour market.

\section{The macroeconomic implications}

The increased segmentation created by the new labour market environment will give rise to a divergence in the path of real wages. Given the significant excess supply of labour and the recessional economic climate, it is likely that the real wage will fall in many segments. However, the final result of such a decline in real wages is difficult to predict. Different pathways of economic adjustment give rise to contradictory effects in responses to a change in real wages. These have different macroeconomic implications. For example, a decline in real wages may have some small positive impact on employment in the longer term due to factor substitution and import/export demand effects. Alternatively, and of much greater significance in the short run, are the negative employment effects which occur through aggregate demand.

Thus in contrast to the assumptions underlying much of the current economic debate, it is probable that raising the real wage in the poorest segments will actually increase employment. Low income households have a high propensity to consume out of current income, and, furthermore, consume a higher proportion of domestically produced goods. This means that raising their wages will increase aggregate demand, and domestic employment .

\section{The wider social costs}

The creation of significantly disadvantaged low paid segments of the labour market will have wider social costs. We have argued that the new legislation is likely to increase the size of the secondary segments of the labour market. Thus more employment will be characterized by low wages, high turnover, casualization, arbitrary discipline, discrimination and alienation. The experience of secondary sector employment will increasingly marginalize sections of the population. The effects of this will be to impose high external costs on society. A decline in wage income will lead to increased crime and

consequent expenditure on the police and judicial systems. The creation of a culture of poverty will heighten the need for increases in various forms of social welfare and health 
expenditure. Furthermore, heightened social distress and inequality is likely to be burdensome to the majority of the population who desire a fair society.

\section{Improving the minimum code}

Most of the adverse effects of the new legislation result from the expansion of the low paid secondary segments of the labour market. Consequently, providing an expanded and improved minimum code of employment conditions will ensure that employers cannot develop the very worst forms of employment. An extensive floor of rights therefore becomes a useful policy instrument, alleviating many of the new legislation's most malignant effects.

Under the new legislation, the meagre nature of statutory minima is a serious problem for some groups because the minimum code will provide their actual terms and conditions of employment. The problem is even more acute for those groups of workers where the protection of the minimum code is only partial. In particular, the absence of a wage floor for workers under 20 years of age will create significant hardship and exploitation of young workers. An adequate minimum code which both provided protection for the disadvantaged, as well as incentives for efficiency, would include the following amendments to that which currently exists:

Minimum wage The level of the minimum wage needs to be increased. An appropriate standard would be the European Decency Threshold which requires the minimum wage to be no less than 68 percent of average adult earnings In New Zealand today, this would translate into approximately $\$ 375$ per week, compared with the current $\$ 245$ per week. Also of utmost concern is the implementation of appropriate minimum wages for workers under 20 years of age. Young workers in the labour market are often relatively powerless and occupy positions vulnerable to exploitation. Social welfare benefits provide de facto minima for many. However they are clearly inadequate, especially given the erosion of their levels and the narrowing of their eligibility criteria.

Leave Entitlements to both holidays and sick leave should be increased. Compared to almost every developed country, the New Zealand holiday and leave provisions are less than adequate (Deakin, 1990).

Hours The code should be improved to give a maximum 40 hour week with a statutory right to higher overtime rates (such as time and a half) for hours worked over and above this.

Minimum notice Employers should be required to give a minimum period of notice (for example 2 weeks), or payments in lieu, before termination of the employment contract. The length of notice should increase with increasing length of service. For the case of redundancy, statute should require a longer minimum notice (such as 2 months). This is particularly important for ensuring that excessive casualization of work is not used by firms as a buffer against economic fluctuations.

Redundancy pay There should be a statutory right to redundancy pay, related to length of service.

Protection against excessive casualization Employers should be prevented from using casualized labour, or other forms of non-standard employment, as a device for avoiding legal requirements, or indeed, the provisions of the minimum code. For example, workers who have worked as casual employees for a certain period should be entitled to the minimum notice, and redundancy pay, if the casual employment 
relationship is terminated. Similarly, casual employees who get appointed to permanent positions should have their service as casuals credited towards any entitlements based on length of service.

Anti-discrimination Anti-discrimination laws should be improved. First, it should once again be mandatory for all large employers to operate equal employment opportunity programs. Secondly, pay equity legislation should be re-introduced. These provisions would go some way towards alleviating the effects of wage discrimination.

Health and safety The current delay in the improvement of occupational health and safety legislation should be brought to an end. The Occupational Health and Safety Bill should be re-introduced in its original form so as to provide an adequately resourced and effective program to prevent work-place injuries.

Monitoring The ability of the Department of Labour to monitor and enforce breaches of the minimum code should be radically improved. Without adequate monitoring, and the punishing of those who fail to comply, the efficacy of the minimum code will be seriously impaired.

Consultation The minimum code should also be improved by the addition of a consultative process to review the code. Groups involved in the negotiation of employment contracts should have an input into both the on-going evaluation of labour market outcomes, and the improvements of the minimum code, on a regular basis.

\section{Conclusion}

Historically the New Zealand system of labour market regulation provided employment protection via the processes of industrial conciliation and arbitration, the social welfare system, and a statutory floor of employment rights. However, because of the current removal of award protection, the erosion of social welfare entitlements, and the recessional state of the labour market, the need for an enhanced minimum code is greater than ever. Increasingly, the provisions of the minimum code will be the prime determinant of the living standards for a significant section of the labour-force.

We have argued that an adequate minimum code of employment protections will promote freedom, social justice and efficiency. Apart from the obvious neglect of social justice, these goals accord with the Minister of Labour's stated reason for the reform of New Zealand labour law (Media statement, 23 April 1991). Given that an extensive minimum code will promote many of the governments labour market objectives, there is a clear argument for immediate legislative action.

Segmentation and an increase in the marginalized employment of disadvantaged groups will produce a labour market where many workers cannot be regarded as free. Freedom in the labour market is crucially dependent on the absence of poverty and exploitation. A strengthened minimum code will therefore protect the liberty of many groups of workers.

Heightened levels of disadvantage within the labour market cannot provide a labour market which accords with the standards of social justice. A labour market where individuals are trapped in a vicious cycle of low pay, discrimination and exploitation does not provide any measure of equal opportunity. The protection afforded by an extensive minimum code will enhance the fairness or social justice of the labour market.

Increased segmentation and the enlargement of secondary sector employment will create inefficiency. Declining real wages provide incentives for the inefficient utilization of labour, the abandonment of training, and a further depression of the economy through the short-term impact on aggregate demand. Inhibiting this process through a 
strengthened minimum code will therefore promote efficiency and growth, and should thus be high on the agenda of any government.

\section{References}

Bowles, S. and Gintis, H. (1975) The problem with human capital theory: a Marxian critique. American economic review 65(2):74-82.

Brosnan, P. and Wilkinson, F. (1989) Low pay and the minimum wage. Wellington, New Zealand Institute of Industrial Relations Research.

Brosnan, P. and Wilson, M. (1989) The historical structuring of the New Zealand labour market. Wellington Industrial Relations Centre, Victoria University of Wellington (Working paper 89/4).

Deakin, S. (1990) The floor of rights in European labour law. New Zealand journal of industrial relations 15(3):219-240.

Doeringer, P.B. and Piore, M.J. (1971) Internal labour markets and manpower analysis. Lexington Massachusetts, Lexington Books.

Hamid, R. (1988) A case for protecting the "dependent contractor". Dip. Ind. Relns. thesis, Victoria University of Wellington.

Harbridge, R. (1990) Flexibility in collective wage bargaining in New Zealand: facts and folklore. New Zealand journal of industrial relations 15(3):241-250.

Humphries, J. and Rubery, J. (1984) The reconstitution of the supply side of the labour market: the relative autonomy of social reproduction. Cambridge journal of economics 8(1):331-346.

Lancaster, K. and Lipsey, R. (1956) The general theory of the second best. Review of economic studies 24(1):11-12.

Mainwaring, T. (1984) The extended internal labour market. Cambridge journal of economics 8(2): 161-187.

Marsden, D. (1986) The end of economic man? Custom and competition in labour markets. Brighton, Wheatsheaf Books.

McAndrew, I. and Hursthouse, P. (1991) Reforming labour relations: what southern employers say. New Zealand journal of industrial relations 16(1):1-12.

Oi, W. (1962) Labour as a quasi-fixed factor. Journal of political economy 70(1):538555.

Roemer, J. (1979) Divide and conquer: micro-foundations of a Marxian theory of wage discrimination. The Bell journal of economics 10(2):695-705.

Rubery, J. (1978) Structured labour markets, worker organisation and low pay. Cambridge journal of economics 8(1): 63-81.

Ryan, P. (1981) Segmentation, duality and the internal labour market. In F. Wilkinson (ed.) The dynamics of labour market segmentation. London, Academic Press.

Treasury (1987) Government management. Wellington, Government Print.

Treasury (1990) Briefing papers to the incoming government. Wellington, The Treasury.

Woods, N. (1963) Industrial conciliation and arbitration in New Zealand. Wellington, Government Printer. 